Elsevier

\title{
Repair of alkylation damage in the fungus Aspergillus nidulans
}

\author{
Richard A. Swirski, Susan G. Shawcross, Barry M. Faulkner and Peter Strike \\ Department of Genetics, University of Liverpool, P.O. Box 147, Liverpool L69 3BX (Great Britain)
}

(Received 4 August 1987)

(Revision received 14 October 1987)

(Accepted 16 November 1987)

Keywords: Alkylation damage, repair; Aspergillus nidulans; Glycosylase activity; DNA methyltransferase activity.

\section{Summary}

The repair of alkylation damage in Aspergillus nidulans was investigated. We have assayed soluble protein fractions for enzymes known to be involved in the repair of this type of damage in DNA. The presence of a glycosylase activity that can remove 3-methyladenine from DNA was demonstrated, as well as a DNA methyltransferase activity that appears to act against $O^{6}$-methylguanine.

In addition to this approach, a series of mutants were isolated which display increased sensitivity to alkylating agents (sag mutants). 5 such mutants were further characterized, and at least 4 are shown to map to genes which have not previously been characterized. The behaviour of double mutant combinations demonstrates the existence of at least 2 pathways for the repair of alkylation damage. The majority of the sag mutants ( $\operatorname{sag} A 1, \operatorname{sag} B 2$, sag4 and $\operatorname{sag} E 5)$ exhibit an increased sensitivity to a range of alkylating agents, but not to UV light, while sagC3, when irradiated at the germling stage, also shows sensitivity to UV. None of the mutants isolated are defective in either the 3-methyladenine DNA glycosylase activity, or the DNA methyltransferase activity, and the nature of the defects in these strains remains to be determined.

The mutagenic and cytotoxic effects of simple alkylating agents have been largely ascribed to their ability to methylate nitrogen or oxygen atoms at a variety of positions in DNA (Lawley and Thatcher, 1970). Studies in Escherichia coli have shown that the mutagenicity of these agents correlates largely with the persistence of the lesion $O^{6}$-alkylguanine (Lindahl, 1982) which preferentially base pairs during replication with thymine

\footnotetext{
Correspondence: Dr. P. Strike, Department of Genetics, University of Liverpool, P.O. Box 147, Liverpool L69 3BX (Great Britain).
}

rather than cytosine, leading to GC to AT transitions (Abbott and Saffhill, 1979). A precise mechanism for the removal of this lesion has been identified in a number of different organisms, including $E$. coli (Cairns et al., 1981; Lindahl, 1982) and various mammalian cell lines (Bogden et al., 1981; Pegg et al., 1982; Yarosh et al., 1983). In each case the mechanism appears to be similar, involving the transfer of the methyl group from the $O^{6}$ position of the base onto an acceptor residue within the methyltransferase repair enzyme. In the case of $E$. coli, the methyltransferase has been identified as a polypeptide of $37000 \mathrm{MW}$ encoded by the ada gene (Olsson and Lindahl, 
1980), with the methyl group being accepted by a cysteine residue at position Cys321 (Sekiguchi and Nakabeppu, 1987). In addition to repair of $O^{6}$ methylation, this enzyme can also accept methyl groups from other methylated oxygens, for example from $O^{4}$-methylthymine (McCarthy et al., 1984) and from methyl-phosphotriesters (Teo et al., 1984), although in this latter case a different acceptor residue is used (Cys69). The mammalian transferases so far characterised appear able only to accept methyl groups from $O^{6}$-methylguanine but not from other lesions (Mehta et al., 1981; Pegg et al., 1983; Dolan et al., 1984).

In $E$. coli, the principle cytotoxic lesion appears to be 3-methyladenine which is effectively removed from DNA by a combination of two glycosylases which are encoded by the alkA and tag genes respectively (Evensen and Seeberg, 1982). Expression of tag appears to be constitutive, while expression of alk $A$, like the ada gene, is inducible by exposure of the cells to low levels of alkylating agents (so-called adaptive response; Samson and Cairns, 1977). The tag gene product is apparently specific for the 3-methyladenine lesion, while the alkA gene product has a broader substrate specificity, acting at 3-methyladenine, 3-methylguanine, $O^{2}$-methylcytosine and $O^{2}$-methylthymine residues (McCarthy et al., 1984).

Some mammalian cell lines have also been reported to show an increased resistance to alkylating agents following exposure to non-lethal inducing levels of these compounds (Samson and Schwarz, 1980; Laval and Laval, 1984). It seems feasible that a response analogous to the adaptive response in $E$. coli could exist in higher eukaryotes. However, attempts to show increased glycosylase activity following adaptation of, for example, rat hepatoma cell line $\mathrm{H}_{4}$, gave equivocal results since the slightly higher 3-methyladenine/7-methylguanine glycosylase activity observed was not sufficient to account for the increased resistance.

In an attempt to characterize repair of alkylation damage in a relatively simple eukaryote, we have turned to the fungus Aspergillus nidulans as a model system. In contrast to yeast (Maga and McEntee, 1985) we have been able to demonstrate the presence of a DNA methyltransferase activity in this organism, as well as alkylation-damage specific DNA glycosylase activity. Several mutants of this organism sensitive to alkylation damage have been isolated previously (Käfer and Mayor, 1986) and we describe here the isolation of further mutants of this phenotype. The construction and characterization of double mutants demonstrates that there are at least two complementary repair pathways for the repair of such damage in this organism. The nature of these repair mechanisms is not yet known, since preliminary results indicate that both glycosylase and methyltransferase activities are not affected in these mutants.

\section{Materials and methods}

\section{Strains}

Strains used were all ultimately derived from the Glasgow stock of $A$. nidulans (Pontecorvo et al., 1953), and as far as could be determined were translocation free. Full details are given in Table 1.

\section{Media and procedures}

Solid growth media, MM (minimal medium) and $\mathrm{CM}$ (complete medium) were prepared as

TABLE 1

\begin{tabular}{|c|c|c|}
\hline Strain No. & Genotype & Source \\
\hline$\overline{\mathrm{R} 21}$ & pabaA1, yA2 & C.F. Roberts \\
\hline R153 & wA3; pyroA4 & C.F. Roberts \\
\hline G96 & $\begin{array}{l}\text { galA1; pyroA4; facA303; } \\
\text { sB3; nicB8; riboB2 }\end{array}$ & A.J. Clutterbuck \\
\hline G128 & anA1, yA2,adE20;wA3 & A.J. Clutterbuck \\
\hline 0110 & biAl; methGl & A.J. Clutterbuck \\
\hline 189 & $a d G 14 ; w A 3$ & F.G.S.C. ${ }^{a}$ \\
\hline 334 & pabaA108, biAl; uvsCl4 & F.G.S.C. ${ }^{a}$ \\
\hline L19 & yA2; pyroA4 & ex $R 21 \times R 153$ \\
\hline $\mathrm{L} 20$ & pabaA1; wA3 & ex R21 1 R153 \\
\hline L130 & yA $2 ;$ pyroA; uvsC 14 & ex $334 \times \mathrm{L} 19$ \\
\hline L451 & As L20, but $\operatorname{sag} A l$ & This paper \\
\hline L452 & As $L 20$ but $\operatorname{sag} B 2$ & This paper \\
\hline L452a & $\begin{array}{l}\text { As L452, but segregant with } \\
\text { normal morphology }\end{array}$ & This paper \\
\hline $\mathrm{L} 453$ & As L20, but $\operatorname{sagC3}$ & This paper \\
\hline L457 & As L20, but sag-4 & This paper \\
\hline L458 & As $L 20$, but sagEs & This paper \\
\hline L455 & yA2; pyroA4; sagB 2 & ex L452 X L19 \\
\hline L456 & yA2, sagC $3 ;$ pyroA4 & ex L453 $\times \mathrm{L} 19$ \\
\hline L460 & pabaA1, wA3, sagC $3 ;$ sagAl & ex $\mathbf{L} 451 \times \mathbf{L} 456$ \\
\hline $\mathrm{L} 472$ & biAl, sagC $3 ;$ methGl & ex $\mathrm{L} 453 \times 0110$ \\
\hline
\end{tabular}

a Fungal Genetics Stock Centre, Department of Microbiology, University of Kansas Medical School. 
described by Pontecorvo et al. (1953), incorporating the modifications of Cove (1966). Where MM was to be supplemented with $N$-methyl- $N^{\prime}$-nitro$N$-nitrosoguanidine (MNNG) or methyl methanesulphonate (MMS), the medium was prepared with $50 \mathrm{mM}$ orthophosphate buffer (OPB), pH 6.0, instead of distilled water (Lawley and Thatcher, 1970).

Conidia were routinely harvested from stock plates in Tween 80 saline $(0.025 \%$ Tween 80 ; $0.08 \% \mathrm{NaCl}$ ). For use in MNNG mutagenesis and MNNG/MMS survival experiments, conidia were resuspended in OPB. Termination of MNNG/ MMS treatment was achieved by dilution into Tween 80 saline containing $1 \%$ sodium thiosulphate.

\section{Isolation of MNNG-sensitive mutants}

All mutants were isolated from a single experiment in which 120 conidia were treated with 0.5 $\mathrm{mg} / \mathrm{ml} \mathrm{MNNG} \mathrm{(final} \mathrm{concentration)} \mathrm{for} 10 \mathrm{~min}$ at $37^{\circ} \mathrm{C}$ and plated onto $\mathrm{MM}+p$-aminobenzoic acid (paba). The surviving fraction was $4 \%$. A random sample of 800 surviving colonies was inoculated onto CM master plates which were then incubated at $37^{\circ} \mathrm{C}$ for $72 \mathrm{~h}$. Colonies were then replicated in duplicate onto $\mathrm{MM}+$ paba plates, with or without MNNG at a final concentration of $3.5 \mu \mathrm{g} / \mathrm{ml}$. Each non-MNNG replica was immediately irradiated with a UV dose of $400 \mathrm{~J} / \mathrm{m}^{2}$ and then the plates were incubated for either 3 days ( $+\mathrm{MNNG}$ ) or 2 days (no MNNG) before scoring. Potential MNNG-sensitive, UV-non-sensitive mutants were transferred to $\mathrm{CM}$ and retested as above.

\section{Tests for MNNG sensitivity}

(a) Radial growth. Approximately $2 \times 10^{5}$ conidia were spot inoculated onto supplemented $M M$ containing various concentrations of MNNG. Plates were incubated at $37^{\circ} \mathrm{C}$ for 72 hours and the radius of each colony measured.

(b) Germination of conidia. Master plates were replicated onto supplemented $\mathrm{MM}$ containing various concentrations of MNNG up to $2.4 \mu \mathrm{g} / \mathrm{ml}$. Replica plates were scored after incubation for 48 h at $37^{\circ} \mathrm{C}$. This procedure was used routinely to score the progeny of sexual crosses.

(c) Survival of conidia. Conidia at a concentration of approximately $2 \times 10^{8} / \mathrm{ml}$ in OPB were treated with $\mathrm{MNNG}(80 \mu \mathrm{g} / \mathrm{ml}$ final concentration) at $37^{\circ} \mathrm{C}$. At suitable time intervals, samples of $100 \mu 1$ were removed into Tween saline $+1 \%$ sodium thiosulphate, and then poured in an overlay onto supplemented MM containing $0.08 \%$ sodium deoxycholate to restrict colony size. Viable colonies were scored after $72 \mathrm{~h}$ incubation at $37^{\circ} \mathrm{C}$.

\section{Test for sensitivity to MMS}

MMS survival curves were constructed as described in section (c) above, with the substitution of $0.15 \% \mathrm{v} / \mathrm{v}$ MMS for MNNG.

\section{Test for UV sensitivity of germinating conidia}

According to the method of Jansen (1970), a suspension of conidia was mixed with melted CM containing $0.04 \%$ sodium deoxycholate and $5-\mathrm{ml}$ samples containing approximately 280 conidia were plated on $15-\mathrm{ml}$ basal layers of the same medium. The plates were incubated for $7 \mathrm{~h}$ at $37^{\circ} \mathrm{C}$ and then irradiated with a UV source at a rate of $1 \mathrm{~J} / \mathrm{m}^{2} / \mathrm{sec}$. Plates were scored after a further $72 \mathrm{~h}$ incubation at $37^{\circ} \mathrm{C}$ in the dark.

\section{Genetic analysis}

Standard procedures were employed for heterokaryon and diploid strain construction, and in the sexual cross and diploid segregation analysis of mutants (Pontecorvo et al., 1953; Käfer, 1958).

\section{Enzyme assays}

\section{(a) DNA glycosylase activity}

Freshly grown mycelium (3-10 g) was ground to a fine powder with an equal weight of acid washed sand in liquid nitrogen. The ground mycelium was added to a small valume (approximately $10 \mathrm{ml}$ per $4 \mathrm{~g}$ of mycelium) of extraction buffer (50 mM MOPS, pH 7.8; $0.8 \mathrm{M} \mathrm{KCl;} 1$ mM EDTA; $1 \mathrm{mM} \beta$-mercaptoethanol; $1 \mathrm{mg} / \mathrm{ml}$ PMSF) and occasionally stirred for $1 \mathrm{~h}$ on ice.

The suspension was centrifuged at $18000 \mathrm{rpm}$ (Sorvall SS34 rotor) for $20 \mathrm{~min}$, and the super- 
natant was dialyzed for $2 \mathrm{~h}$ against 2 litres of extraction buffer containing no $\mathrm{KCl}$, and then used in the assay.

The standard reaction mixture $(0.1 \mathrm{ml})$ contained $50 \mathrm{mM}$ MOPS, pH 7.8; $7 \mathrm{mM}$ EDTA; 1 $\mathrm{mM}$ dithiothreitol (DTT), 5\% glycerol, and $6 \mu \mathrm{g}$ of $\left[{ }^{3} \mathrm{H}\right]$ dimethyl-sulphate-treated DNA (2600 cpm). The reaction was started by the addition of a limiting amount of enzyme preparation (usually in the range of $0-300 \mu \mathrm{g}$ of protein), followed by incubation at $37^{\circ} \mathrm{C}$. After incubation, the reaction mixtures were chilled to $0^{\circ} \mathrm{C}$ and $10 \mu 10.2 \%$ heat-denatured calf thymus DNA, $10 \mu \mathrm{l} 5 \mathrm{M}$ $\mathrm{NaCl}$ and $300 \mu 1$ ice-cold ethanol were added. The samples were kept at $-20^{\circ} \mathrm{C}$ for $30 \mathrm{~min}$ and were then centrifuged at $10000 \mathrm{rpm}$ (Sorvall GSA rotor) for $30 \mathrm{~min}$. $200 \mu 1$ of each supernatant were recovered, added to scintillation fluid, and the radioactivity released determined in a scintillation counter.

\section{(b) DNA methyltransferase assay}

Freshly grown mycelium was ground with sand as described above and added to extraction buffer which, in this case, contained $10 \mathrm{mM}$ Tris, $\mathrm{pH} 7.2$; $1 \mathrm{mM}$ EDTA; $1 \mathrm{mM} \beta$-mercaptoethanol; $1 \mathrm{mg} / \mathrm{ml}$ PMSF. Following centrifugation as described above, the supernatant was decanted and kept (Fraction I).

To $15-20 \mathrm{ml}$ of Fraction I was added one tenth volume of $5 \%$ polyethyleneimine (neutralised and dialyzed against extraction buffer), with gentle stirring. Stirring was continued on ice for $60 \mathrm{~min}$, until a viscous solution had formed. This was centrifuged for $15 \mathrm{~min}$ at $18000 \mathrm{rpm}$ (Sorvall SS34 rotor) and the supernatant dialyzed for $4 \mathrm{~h}$ against dialysis buffer (as extraction buffer, PMSF and 5 $\mathrm{mM} \beta$-mercaptoethanol). The dialyzed sample was centrifuged briefly to remove any insoluble material and the supernatant was kept as Fraction II.

Fraction II was brought to $100 \%$ saturation with ammonium sulphate by the slow addition of crystals with continuous gentle stirring. $0.1 \mathrm{~g}$ of streptomycin sulphate was similarly added and gentle stirring was continued for $1 \mathrm{~h}$ on ice. The protein precipitate was then pelleted by centrifugation at $18000 \mathrm{rpm}$ for $20 \mathrm{~min}$ (Sorvall SS34 rotor) and was resuspended in a minimal volume of extraction buffer prior to dialysis overnight against 6 litres of dialysis buffer (Fraction III).

Fraction III was then sequentially dialyzed against buffer containing 20-50\% glycerol, and was stored at $-20^{\circ} \mathrm{C}$ for no longer than one week before it was assayed (Fraction IV).

Methyltransferase activity was assayed by adding $7 \mu \mathrm{g}(22500 \mathrm{cpm})$ of $\left[{ }^{3} \mathrm{H}\right] \mathrm{methylnitrosourea}$ (MNUA)-treated DNA to a total volume of $1 \mathrm{ml}$ of TED buffer $\left(10^{-2} \mathrm{M}\right.$ Tris $\mathrm{pH} 8.0 ; 10^{-3} \mathrm{M}$ EDTA; $1 \mathrm{mM}$ DTT). The reaction was initiated by the addition of up to $950 \mu 1$ of Fraction IV, followed by incubation at $37^{\circ} \mathrm{C}$ for $30 \mathrm{~min}$.

Protein and DNA were subsequently precipitated by the addition of $400 \mu 13 \mathrm{M}$ trichloroacetic acid (TCA), and the DNA hydrolyzed by heating at $70^{\circ} \mathrm{C}$ for $30 \mathrm{~min}$. The sample was cooled to ice temperature, a further $2 \mathrm{ml}$ of $1 \mathrm{M} \mathrm{TCA}$ was added, and the protein precipitate was pelleted by centrifugation at $5000 \mathrm{rpm}$. The supernatant was discarded and the pellet was dissolved in $400 \mu 1$ of $10 \mathrm{mM} \mathrm{NaOH}$. Scintillation fluid was added and the radioactivity determined in a scintillation counter.

\section{Preparation of DNA substrates}

(a) Glycosylase assay. Deproteinised calf thymus DNA (Sigma) at $1.5 \mathrm{mg} / \mathrm{ml}$ was treated with $1 \mathrm{mCi} / \mathrm{ml} \mathrm{[}{ }^{3} \mathrm{H}$ ]dimethyl sulphate (New England Nuclear) in $0.25 \mathrm{M}$ potassium cacodylate buffer, pH 7.4; $1 \mathrm{mM}$ EDTA at $37^{\circ} \mathrm{C}$ for $1 \mathrm{~h}$ in the dark. The reaction was terminated by chilling on ice and the addition of 2 vol. of ethanol. DNA was spooled onto a glass rod, sequentially washed in $70 \%, 80 \%$ and $90 \%$ ethanol, and then dissolved in $1 \mathrm{M} \mathrm{NaCl}$; $10 \mathrm{mM}$ Tris, pH 7.4; $1 \mathrm{mM}$ EDTA at $4^{\circ} \mathrm{C}$. The DNA solution was dialyzed against the same buffer overnight, and then for $3 \mathrm{~h}$ against the same buffer but without $\mathrm{NaCl}$ prior to storage at $-70^{\circ} \mathrm{C}$.

(b) DNA methyltransferase assay. Deproteinised calf thymus DNA (Sigma) was dissolved at a final concentration of $8 \mu \mathrm{g} / \mathrm{ml}$ in $3 \mathrm{mM}$ Tris, pH 8.0. This solution $(1 \mathrm{ml})$ was reacted with ${ }^{3} \mathrm{H}$-MNUA (30 Ci/mMole, Amersham International) by agitation at room temperature for $3 \mathrm{~h}$, was then cooled to ice temperature, and the DNA 
precipitated by the addition of $2 \mathrm{vol}$. of ethanol. The DNA was washed extensively with $70 \%$ ethanol prior to dialysis against $10 \mathrm{mM}$ Tris, $\mathrm{pH}$ $7.2 ; 0.15 \mathrm{M} \mathrm{NaCl} ; 1 \mathrm{mM}$ EDTA. Finally the DNA was reprecipitated with ethanol and then dissolved in $10 \mathrm{mM}$ Tris, $\mathrm{pH} \mathrm{7,2} \mathrm{mM}$ EDTA prior to storage at $-20^{\circ} \mathrm{C}$.

This substrate was the generous gift of Dr. G. Margison.

\section{Protein determination}

Protein concentrations were determined using a Coomassie Blue G250 Assay Kit from BioRad Laboratories Ltd.

\section{Preparation of extracts from $E$. coli}

Extracts were prepared from $E$. coli strain AB1157 by the method of Seeberg et al. (1976). Cells were grown to early log phase, plasmolyzed in $2.5 \mathrm{M}$ sucrose and then gently lysed with lysoszyme. Following centrifugation at $20000 \mathrm{~g}$ for 15 min, the supernatant was taken for assay. To induce the adaptive response enzymes, cells were grown for $2 \mathrm{~h}$ in the presence of $0.5 \mu \mathrm{g} / \mathrm{ml}$ MNNG prior to extract preparation.

\section{Thin-layer chromatography}

Counts released from DNA by DNA glycosylase activity were co-chromatographed with pure 3-methyladenine on silica gel TLC plates (Sigma). The solvent system contained methanol and water in the ratio $3: 1$. The 3-methyladenine was visualized under UV, and the corresponding area was scraped off the plates and counted in scintillation fluid. As controls, areas in front of and behind the 3-methyladenine spot were also counted.

\section{Results}

\section{Measurement of DNA glycosylase activity}

Fig. 1 shows release of counts from $\left[{ }^{3} \mathrm{H}\right] \mathrm{di}$ methyl sulphate-treated DNA by glycosylase activity in soluble protein extracts prepared from the wild-type $A$. nidulans strain L20. Panel A shows a protein titration curve, panel B a time course experiment. In each case, a plateau level was reached of approximately $16 \%$ total counts released. In a similar assay performed with extracts prepared from $E$. coli, an adapted extract

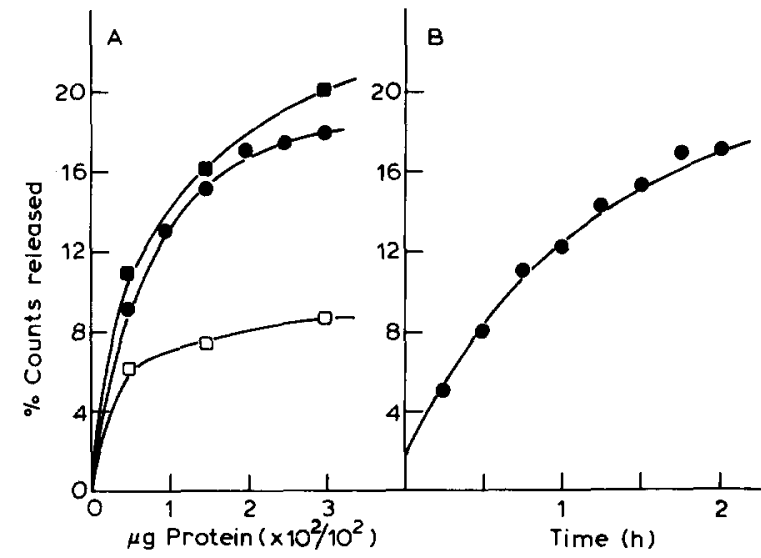

Fig. 1. Release of ${ }^{3} \mathrm{H}$ counts from $\left[{ }^{3} \mathrm{H}\right]$ dimethyl sulphate (DMS)-treated DNA by soluble extracts of $E$. coli K12 AB1157 and Aspergillus nidulans L20. Preparation of substrate and extracts is described in Materials and Methods. Panel A: Symbols are as follows (e) A. nidulans L20; ( AB1157, induced for the adaptive response by growth in the

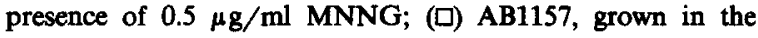
absence of MNNG. The amounts of protein added were in the range of $0-30 \mu \mathrm{g}$ for $\mathrm{AB1157}$, and in the range $0-300 \mu \mathrm{g}$ for L20. Substrate used was $6 \mu \mathrm{g}$ of DMS-treated calf thymus DNA at $433 \mathrm{cpm} / \mu \mathrm{g}$, and incubation was for $45 \mathrm{~min}$ at $37^{\circ} \mathrm{C}$. Panel B: As panel A, but a time course experiment using a fixed amount $(50 \mu \mathrm{g})$ of protein prepared from L20.

released approximately $20 \%$ and an unadapted extract released approximately $8 \%$ of the total counts (Panel A). Thus the amount of radioactivity released by the $A$. nidulans enzyme was intermediate between these two. The glycosylase activity was not inhibited by $3 \mathrm{mM}$ 3-methyladenine, nor was its activity altered in any way by a variety of treatments in which the fungal mycelium was exposed to various non-lethal levels of $\mathrm{MNNG}$ prior to preparation of the extracts. These treatments include $2 \mathrm{~h}$ germination of spores followed by (a) $18 \mathrm{~h}$ exposed to $1.5 \mu \mathrm{g} / \mathrm{ml} \mathrm{MNNG} \mathrm{(b)} 17 \mathrm{~h}$ growth, $+4 \mathrm{~h}$ exposure to $80 \mu \mathrm{g} / \mathrm{ml} \mathrm{MNNG} \mathrm{(c)}$ $12 \mathrm{~h}$ exposure to $50 \mu \mathrm{g} / \mathrm{ml} \mathrm{MNNG}$, addition of a further $50 \mu \mathrm{g} / \mathrm{ml} \mathrm{MNNG} \mathrm{and} \mathrm{incubation} \mathrm{for} \mathrm{a}$ further $4 \mathrm{~h}$, and (d) $17 \mathrm{~h}$ growth $+4 \mathrm{~h}$ exposure to $500 \mu \mathrm{g} / \mathrm{ml}$ and $\mathrm{MNNG}$.

The extent of removal of methylated bases by $A$. nidulans extracts was consistent with 3-methyladenine being the primary lesion recognized, although the higher plateau reached compared to non-induced $E$. coli suggested that a number of 


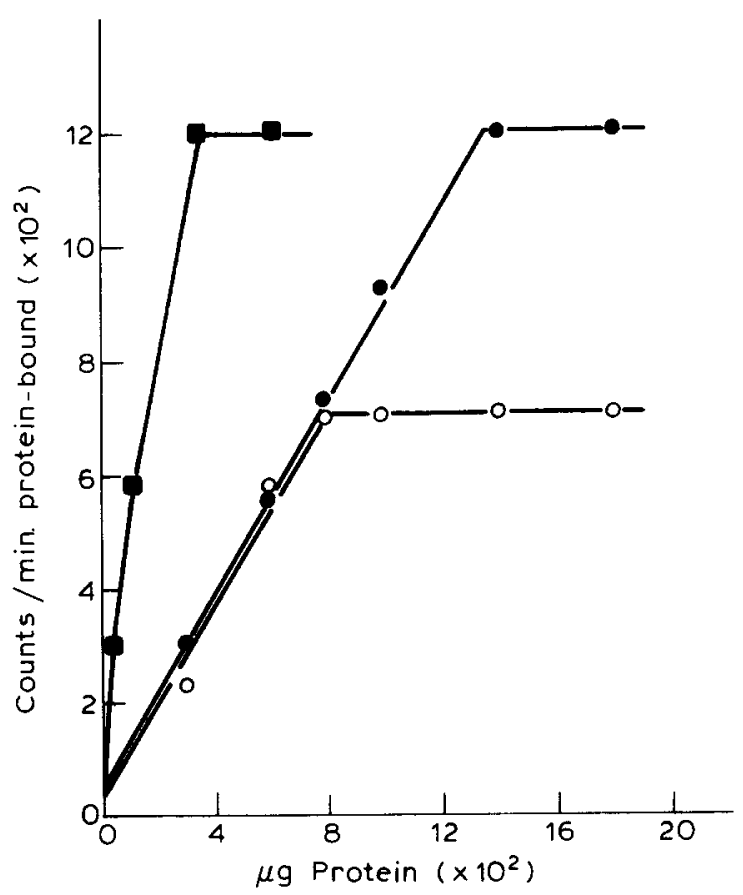

Fig. 2. DNA methyltransferase assays of soluble protein fractions prepared from $E$. coli $\mathrm{K} 12 \mathrm{AB} 1157$ and $A$. nidulans $\mathrm{L} 20$. Symbols are as follows ( $\square$ ) AB1157, fresh extract (๑) L20, fresh extract; (O) L20, extract frozen for $18 \mathrm{~h}$, thawed and assayed. Substrate was $7 \mu \mathrm{g}$ of ${ }^{3} \mathrm{H}-\mathrm{MNUA}$-treated DNA at 3200 $\mathrm{cpm} / \mu \mathrm{g}$.

minor lesions might also be recognised. In support of this conclusion, the majority of the counts $(\sim 60 \%)$ released into the alcohol-soluble factions by the protein extract co-chromatographed with pure 3-methyladenine (Sigma) when analyzed by thin-layer chromatography (see Materials and Methods).

\section{Measurement of DNA methyltransferase activity}

In addition to a DNA glycosylase activity specific for methylated DNA, a DNA methyltransferase activity could also be detected. Initial attempts to demonstrate methyltransferase activity in crude extracts were unsuccessful, and it was found necessary to perform several purification steps (outlined in Materials and Methods) before the activity could be seen.

Fig. 2 shows the results of assaying semi-purified $A$. nidulans fractions by the methyltransferase assay of Margison et al. (1985) using ${ }^{3} \mathrm{H}-\mathrm{MNUA}$ treated DNA as a substrate. The transfer of ${ }^{3} \mathrm{H}$ counts from DNA to a protein fraction could be detected, up to a plateau level similar to that observed for extracts prepared from induced $E$. coli cells. The $E$. coli enzyme is capable of removing methyl groups from both the $O^{6}$ position of guanine, and from methyl-phosphotriesters (Teo et al., 1984). These products were present in approximately equal amounts in the substrate used (G. Margison, personal communication). The observation that the $A$. nidulans extract could remove the same number of counts from MNUAtreated DNA as could $E$. coli may imply that both types of lesions were being removed. If this is so, this would make the $A$. nidulans enzymes unique amongst the eukaryote transferases so far identified, since all others reported to date appear to be active only against $O^{6}$-methylguanine, and not against methyl-phosphotriesters. Further work to confirm this point, using substrates containing defined lesions, is currently in progress.

In order to detect these levels of transferase activity, we have found it essential to use freshlyprepared extract. If fraction IV was kept at $-20^{\circ} \mathrm{C}$ (in the presence of glycerol to prevent freezing) for $18 \mathrm{~h}$, and the sample was reassayed, the plateau level fell consistently to approximately $50 \%$ of the level observed with fresh extracts and then remained constant (Fig. 2). Whether this loss of activity was specific for one type of lesion is not yet clear.

\section{Mutant isolation and characterization}

Given that enzymes involved in the repair of methylated DNA could be detected in crude extracts of $A$. nidulans, we proceeded to isolate mutants sensitive to MNNG which we hoped might be defective in these enzymes.

Following MNNG mutagenesis of strain L20 ( $p a b a A 1 ; w A 3$ ), 20 MNNG-sensitive mutants were isolated, of which 15 were also sensitive to UV, as judged by irradiation of resting conidia. The other 5 mutants were not UV-sensitive as judged by this criterion and were chosen for further study. $\mathrm{MM}+p$-aminobenzoic acid (paba) plates were used for scoring surviving fractions and isolation of MNNG-sensitive mutants, in an attempt to exclude mutants in metabolic pathways other than those involved in DNA repair that may have displayed sensitivity to MNNG (Käfer, 1987). 
TABLE 2

SENSITIVITIES OF MUTANT STRAINS TO MNNG AS DETERMINED BY MEASUREMENT OF RADIAL GROWTH

\begin{tabular}{|c|c|c|c|c|c|c|c|c|}
\hline \multirow[t]{2}{*}{ Strain } & \multicolumn{8}{|c|}{ MNNG concentration $(\mu \mathrm{g} / \mathrm{ml})$} \\
\hline & 0 & 0.5 & 1.0 & 1.5 & 2.0 & 2.5 & 3.0 & 3.5 \\
\hline sagl & $100 \quad 100$ & 65 & 10 & & & & & \\
\hline sag2 & $100 \quad 100$ & 90 & 30 & 10 & & & & \\
\hline sag 3 & $100 \quad 100$ & 98 & 85 & 48 & 16 & & & \\
\hline sag4 & $100 \quad 100$ & 100 & 80 & $31 \quad 47$ & 32 & $\begin{array}{l}5 \\
-\end{array}$ & & \\
\hline sag 5 & 100 & 100 & 86 & $64 \quad 90$ & $31 \quad 60$ & $14 \quad 20$ & $3 \quad 20$ & \\
\hline L20 & 100 & 100 & 100 & $62 \quad 75$ & $51 \quad 75$ & $29 \quad 30$ & $22 \quad 30$ & 30 \\
\hline
\end{tabular}

\% Radial growth

$72 \mathrm{~h}$ at $37^{\circ} \mathrm{C}$

Two measurements were made, one to assess the sensitivity at the conidial stage, the other to assess the sensitivity of growing hyphae. The upper right figures were obtained by spot inoculations of approximately $2 \times 10^{5}$ conidia onto MM plates, followed by incubation for $72 \mathrm{~h}$ at $37^{\circ} \mathrm{C}$. The lower left figures were obtained by placing approximately $3 \mathrm{~mm}^{2}$ of mycelium cut from a colony growing on plates without MNNG onto appropriate MM plates before incubation at $37^{\circ} \mathrm{C}$ for $72 \mathrm{~h}$. The order of sensitivities of the mutant strains was the same in each case.

The relative MNNG sensitivity of these sag mutants (Sensitivity to Alkylating agents) was measured in two ways, first by direct measurement of radial growth (Table 2 ) and second by measuring conidial survival (Fig. 3). On the basis of sensitivity, the mutants were allocated mutation numbers, sag- 1 being the most sensitive, sag- 5 the least. When grown in the absence of MNNG, each of the strains was indistinguishable from wild-type, with the single exception of sag-2. This isolate had radial grooves on its surface, secreted a dark brown pigment into the medium and displayed a radial growth rate only $50 \%$ that of $\mathrm{sag}^{+}$. This complex phenotype appeared to be the result of multiple mutations, and not a direct consequence of the sag-2 mutation, since during serial subculture some sag-2 colonies produced sectors of normal morphology which were still MNNG sensitive. Apart from the initial MNNG-sensitivity tests (Table 2 and Fig. 3), and the subsequent mutational origin and dominant/recessive tests, all further analyses of sag-2 were performed with material derived from one of these normal-morphology segregants, designated strain $\mathrm{L} 452 \mathrm{a}$, or from recombinant strain L455, described in the following section.

\section{Mutational origins of sag mutants}

Sag mutants 1 to 4 were each crossed with strain L19 ( $y$ A2; pyroA4) and the progeny were analyzed. Because of the difficulty in accurately scoring the slight MNNG sensitivity of mutant sag-5, this strain was not included in this test.

In each cross the sag and sag $^{+}$alleles segregated $1: 1$ in the progeny, indicating that the MNNG sensitivity was due to a single gene mutation. The complex nature of the initial sag-2 isolate (strain L452) was further demonstrated by the presence amongst the L452 $\times$ L19 progeny of a number of colonies which had the sag-2 level of MNNG sensitivity associated with normal morphology. One of these colonies was retained as strain L455.

\section{Dominant / recessive allele tests}

Diploids heterozygous for the sag mutations were constructed from the haploid strains $L 451 \times$ G96 (sag-1/+ ), L452 × G96 (sag-2/ + ), L453 × 


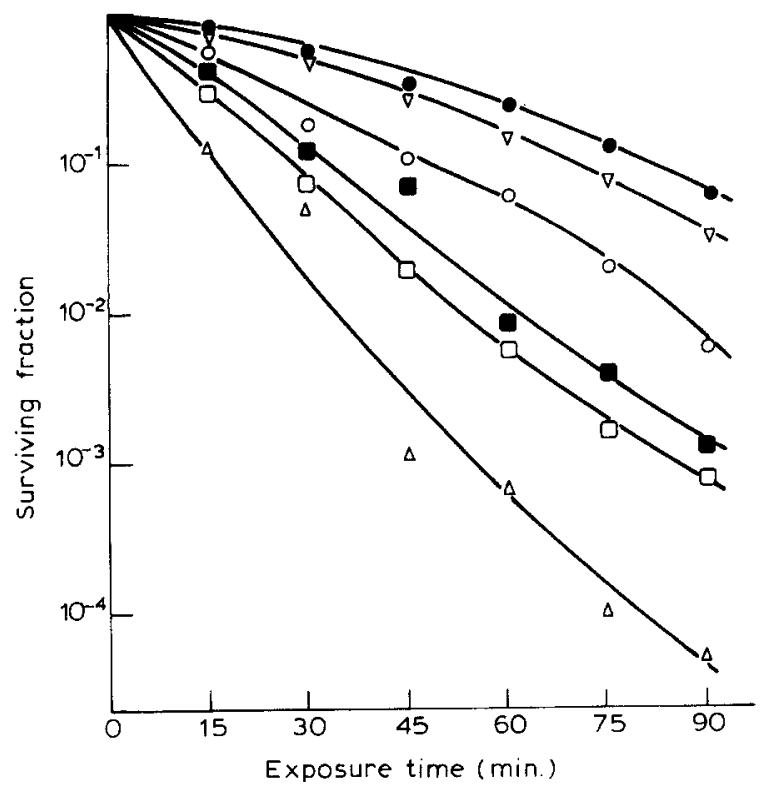

Fig. 3. Conidial survival curves of MNNG-sensitive mutants derived from L20. Conidia were treated with MNNG at a concentration of $80 \mu \mathrm{g} / \mathrm{ml}$ for the times indicated, and were then plated to assess survival. Each survival curve was repeated at least 3 times, and a typical example is given. To ensure comparability, each curve is derived from conidia treated at the same time with the same batch of MNNG. This protocol was adopted to avoid the inevitable variations in MNNG concentration due to the instability of the compound in aqueous solution. Symbols are as follows: $\bullet, \mathrm{L} 20 ; \nabla, \mathrm{L} 458$ sag-5; $\mathrm{O}$, L457 sag-4; 口, L453 sag-3; 口, L452 sag-2; $\Delta$, L451 sag-I.

G96 (sag-3/+), L457 × G96 (sag-4/+) and L458 $\times$ G96 (sag-5/ + ). A + / + control diploid was constructed from strains L $20 \times$ G96.

When the MNNG sensitivity of these diploids was measured each displayed exactly the same response as the $+/+$ control (data not shown). This seems to indicate that each of the 5 sag alleles is fully recessive to the wild-type allele.

\section{Mapping to mitotic linkage groups (chromosomes)}

The 3 most sensitive mutations, 1, 2 and 3 were mapped to linkage groups by Benlate haploidization (Hastie, 1970) of their respective heterozygous diploids described above. In these diploids all eight chromosomes were genetically marked as follows:

\footnotetext{
I: paba A1/+ ; II: $w A 3 /+$ : III: +/galA1; IV: + /pyroA4;

$\mathrm{V}:+/$ facA303; VI: +/sB3; VII: +/nicB8;

VIII: $+/$ riboB2.
}

The genotypes of haploid segregants were analyzed for association of each sag mutation with a particular chromosome marker. In the case of sag-1, among 46 haploid segregants from diploid L451/G96, 42 were either riboB2 ${ }^{+}$sag-1 or riboB2 sag $-1^{+}$, and 4 were unscorable for these markers. All the other chromosome markers associated freely with sag- $I$ indicating that it was located on chromosome (linkage group) VIII. Similar data located sag-2 on chromosome VIII and sag-3 (now designated sagC3 as it was not allelic with any of the other mutations) to chromosome $I$. Of the less sensitive mutants sag- 4 has now been assigned to chromosome VIII and sag-5 (now designated sagE5) to chromosome VI.

\section{Sexual crosses}

\section{(a) Allelism and mapping}

Similarity of phenotype and apparent location on chromosome VIII, raised the possibility that the sag-1, sag-2 and sag-4 mutations might be allelic. sag strains L451 (pabaA1; wa3; sag-1) and L455 ( $y A 2$; pyroA4; sag-2) were crossed, and 80 progeny analyzed for MNNG sensitivity. 12 colonies were scored as $\mathrm{sag}^{+}, 14$ displayed extreme sensitivity to $\mathrm{MNNG}$ and the remainder were sensitive within the sag-1 to sag-2 range. We therefore conclude that sag- 1 and sag- 2 are mutations of different genes, $\operatorname{sag} A$ and $\operatorname{sag} B$ with an RF (recombination frequency) value of 0.32 , i.e. they are separated by 32 map units. We have yet to determine whether or not sag-4 is an allele of either $\operatorname{sag} A$ or $\operatorname{sag} \mathrm{B}$, but mapping is currently in progress.

\section{(b) Epistatic grouping}

Among the progeny from the L451 $\times$ L455 cross described above, recombinants with wild-type MNNG resistance could be detected, and also a similar number of recombinants showing a greater sensitivity than L451 were observed. We assume that this class represents the $\operatorname{sag} A 1 \operatorname{sagB2}$ double mutant which therefore appears more sensitive than either of the single mutant parent strains. We conclude therefore that these two genes do not belong to the same epistatic group.

Sag strains L451 (pabaA1; wA3; sagA1) and L456 (sagC3, yA2; pyroA4) were also crossed to 


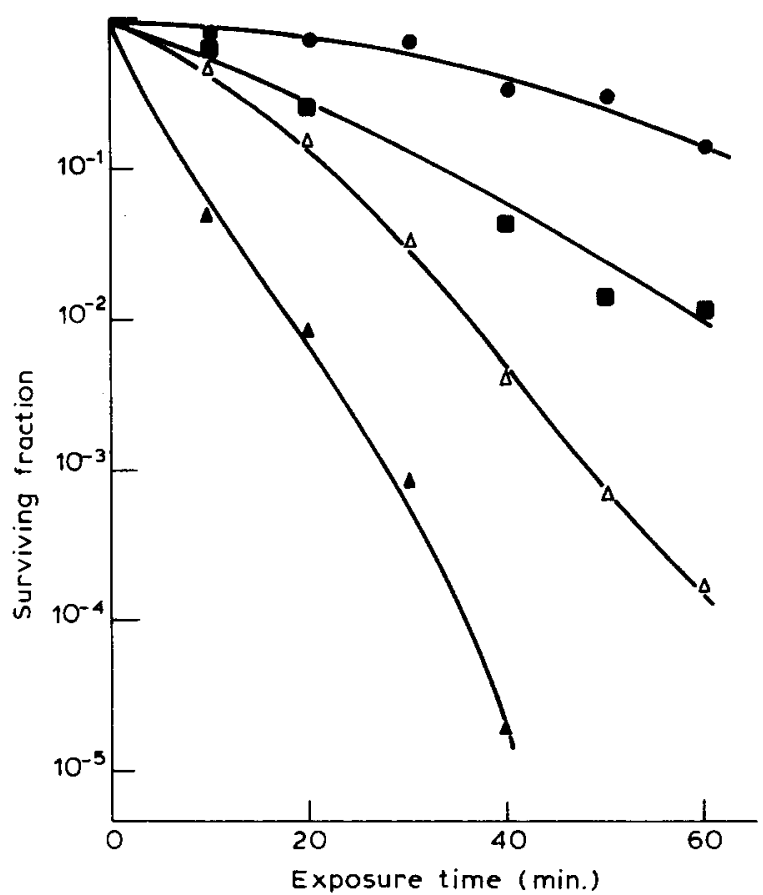

Fig. 4. Conidial survival curves of MNNG-sensitive mutants L451 sag $A l(\Delta)$ and L453 sagC3 (D) compared to wild-type L20 (๑) and the double mutant L460 sagC3; sagAI (A). Conidia were treated with MNNG at $80 \mu \mathrm{g} / \mathrm{ml}$ for the times indicated, and were then plated to assess survival. All samples were treated simultaneously with the same batch of MNNG, and a typical result is shown.

produce the double mutant sagC3; sagA1. The 100 progeny tested fell into 4 phenotypic groups with respect to MNNG sensitivity, in the ratio $1: 1: 1: 1\left(\chi_{[3]}^{2}=0.88,0.7>P<0.9\right)$. 26 progeny were wild-type, 26 like sagC3, 21 like sagAl and 27 displayed extreme sensitivity, being much more sensitive than sagAI. One such hyper-sensitive colony (also pabaA1; wa3 - strain L460), was crossed with strain L19 ( $y A 2 ;$ pyroA4), and the progeny assessed for $\mathrm{MNNG}$ sensitivity. Of 80 colonies tested, 16 were like sagAl, 23 like $s a g C 3$, 21 were wild-type and 20 were extremely MNNG sensitive in a $1: 1: 1: 1$ ratio $\left(\chi_{[3]}^{2}=1.3,0.7>P>\right.$ $0.9)$ demonstrating clearly that $L 460$ is a double mutant strain, and that the sagAl and sagC3 alleles segregate independently.

Fig. 4 shows MNNG survival curves of the sagC3; sagAI double mutant, compared to the single mutant and wild-type strains. The additivity of the sensitivities is clearly seen, i.e. the two mutations belong to different epistatic groups.

\section{(c) Mapping within linkage groups}

The location of sagC 3 to chromosome I raised the possibility that this mutation might be an allele of a gene affecting radiation/mutagen sensitivity which had previously been mapped to this linkage group. In particular, the $u v s F$ gene, which affects UV, MNNG and MMS sensitivity (Shanfield and Käfer, 1969; Käfer and Mayor, 1986) and the uvs $A$ gene, which affects UV and MMS sensitivity (Jansen, 1969; Käfer and Mayor, 1986), have both been mapped to this chromosome. In order to precisely locate the sagC3 gene it was mapped with respect to flanking markers in the crosses L472 (sagC3; biAl; methG1) $\times \mathrm{G} 128$

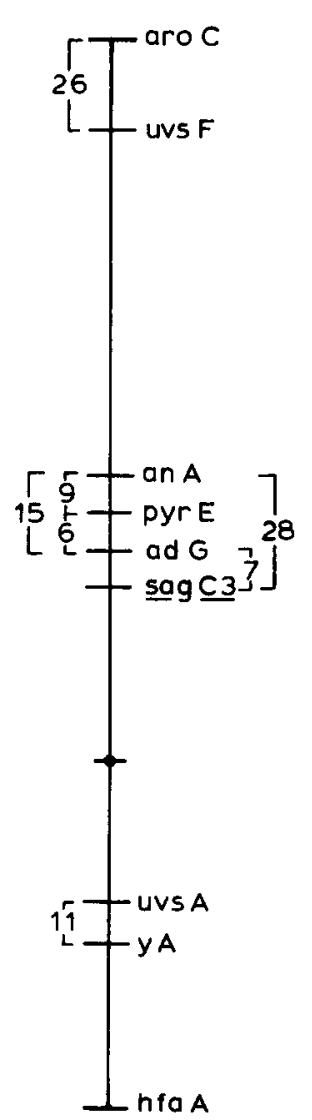

Fig. 5. Genetic map of chromosome I showing the linkage of sagC3 to flanking markers. Map distances shown to the left are taken from the standard $A$. nidulans map, distances to the right were determined in this work. 
(anA1; yA2, adE20; wA3) and L456 (sagC3, yA2; pyroA4) $\times 189$ (adG14;wA3). We observed sagC3 to map 7 map units from adG14, and 28 map units from anAl, consistent with the genetic map shown in Fig. 5 and demonstrating that sagC3 maps in a quite different place from either $u v s F$ or $u v s A$.

\section{Cross-sensitivity to other DNA-damaging agents}

Our intention in starting this work was to isolate mutants specifically defective in the repair of alkylation damage. The mutants were initially isolated as sensitive to $\mathrm{MNNG}$ (an $\mathrm{SN}_{1}$ reagent) which gives a typically different spectrum with respect to the relative frequencies of DNA lesions as compared to $\mathrm{SN}_{2}$ reagents such as methyl methanesulphonate (MMS) (Lawley, 1966).

Sag 1-5 mutants were therefore tested for their sensitivity to MMS, and also to the ethylating agent ethyl methanesulphonate (EMS). We observed that in each case, the MMS sensitivity of the strain paralleled the MNNG sensitivity. The

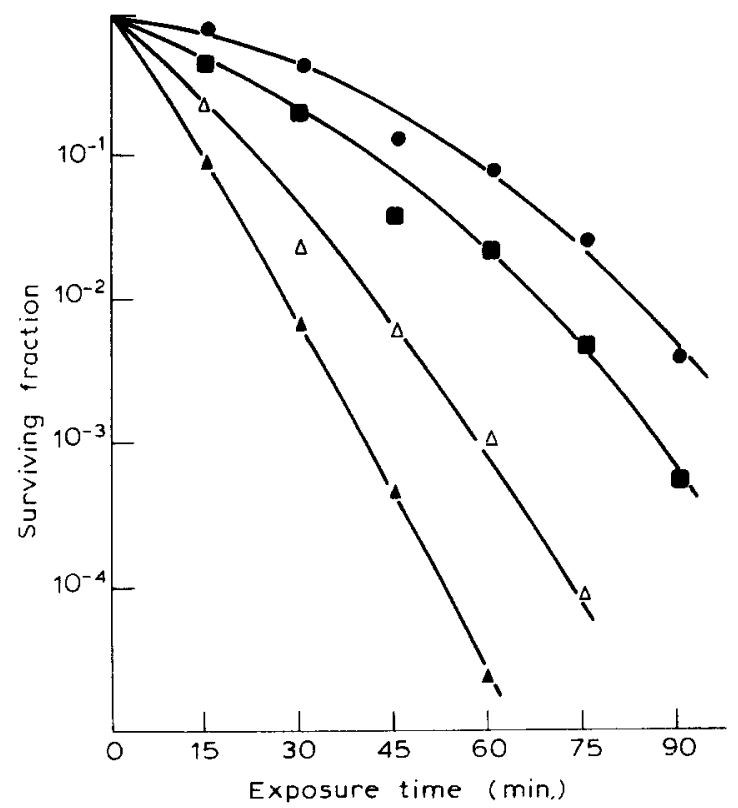

Fig. 6. Survival curves of MMS-treated conidia from mutants

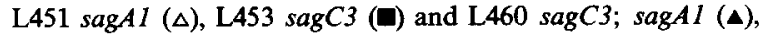
compared to wild-type L20 (e). All samples were treated simultaneously with the same batch of MMS, and a typical result is shown. Treatment was with $0.15 \% \mathrm{v} / \mathrm{v}$ MMS for the time periods shown. data for $\operatorname{sag} A 1$, sagC3 and $\operatorname{sagC3}$; sagA1 double mutants are given in Fig. 6 - again the double mutant was much more sensitive than either of the single mutant parents. Mutants sag-4 and sagE-5 showed only a very slight sensitivity to MMS. Similar data were obtained with EMS, although the level of sensitivity for a particular concentra. tion of alkylating agent was, for each mutant, less than with MMS.

During the initial isolation of mutants, we had discarded those which were obviously sensitive to UV. However, some A. nidulans mutants e.g. uvsC14 (Jansen, 1970) only display UV sensitivity when irradiated at the germling stage. In order to determine whether this was the case with any of our mutants, UV survival curves were constructed where the irradiation dose was given $7 \mathrm{~h}$ after the onset of germination. Under these conditions, all

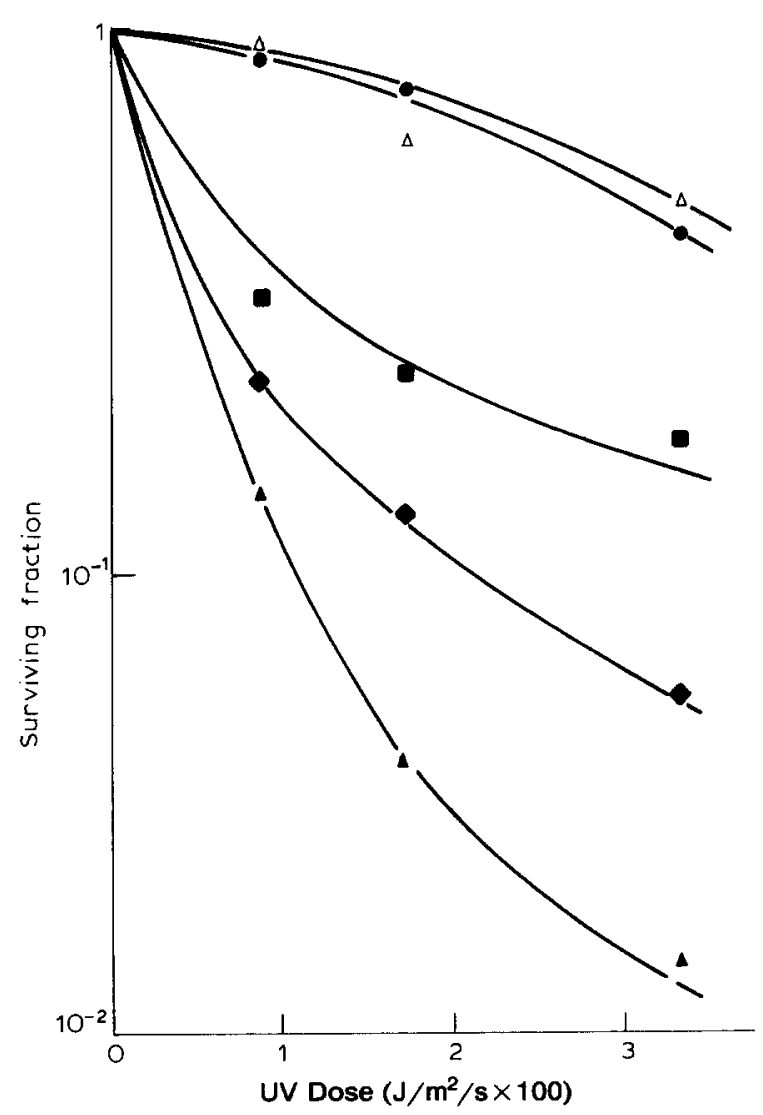

Fig. 7. UV-survival curves of conidia from L20 (e); L451

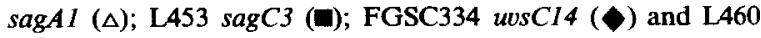
sagC3; sagAl (A). A typical result is shown. 
of the mutants except sagC3 showed wild-type sensitivity (Fig. 7). The sagC3 strain showed marked UV-sensitivity and the double mutant sagC3; sagAl showed even greater sensitivity, despite the fact that sagAI was not all UV-sensitive in isolation.

DNA glycosylase and DNA methyltransferase activities in mutant strains

As described in the introduction, it was hoped that by isolating mutants showing increased sensitivity to MNNG, it might be possible to isolate those defective specifically in DNA glycosylase or in DNA methyltransferase activity. The observation that all of our mutants were also sensitive to MMS and EMS made it appear unlikely that they were affected in transferase activity, since there is relatively little $O^{6}$-methylation by $\mathrm{SN}_{2}$ reagents. This was confirmed by enzyme assays, where we were able to detect normal levels of transferase activity in all of the mutant strains.

Sensitivity to both $\mathrm{SN}_{1}$ and $\mathrm{SN}_{2}$ alkylating agents could be consistent with a defect in DNA glycosylase activity acting on, for example, 3-methyladenine, although defects in several other enzymes would also be predicted to have to same effect. Assays for glycosylase activity revealed that methylated bases (primarily 3-methyladenine) were removed efficiently from DNA by cell-free extracts of all the mutant strains sag 1-5. The repair defect is, therefore, presumed to lie elsewhere.

\section{Discussion}

We have begun an analysis of the repair of alkylation damage in Aspergillus nidulans using a 2-fold approach, namely the identification of enzymes involved in the repair processes and the isolation of mutants specifically sensitive to alkylating agents.

The enzymes involved in the repair of alkyl lesions can be detected in crude extracts of $A$. nidulans, provided simple precautions are taken to prevent non-specific nuclease activity and to remove substances which apparently bind to DNA and prevent access by repair enzymes. Under these conditions we have demonstrated the presence of a glycosylase which removes primarily 3-methyladenine from DNA, and also a DNA methyltrans- ferase which acquires methyl groups from methylated DNA and transfers them to a protein moiety, presumably itself. The amount of counts removed is consistent with an enzyme activity capable of removing methyl groups from both the $O^{6}$ position of guanine and from alkylphosphotriesters in the DNA backbone, since the plateau level of protein bound counts removed from methylated DNA is exactly the same using $E$. coli cell-free extracts and extracts prepared from $A$. nidulans, and the $E$. coli enzyme is known to remove lesions from both of these positions. A rigorous investigation of the question is currently being undertaken. If the $A$. nidulans enzyme does have activity against both of these types of lesion, this would be a novel situation in eukaryotes since all other eukaryotic transferases so far characterized are reported to be active only against $O^{6}$-methylguanine and to have no activity against alkylphosphotriesters (e.g. Dolan et al., 1984). However, during our work with the $A$. nidulans enzyme, we repeatedly observed that if the methyltransferase preparations were kept at $4^{\circ} \mathrm{C}$ for $16 \mathrm{~h}$ and then reassayed, the activity fell to approximately $50 \%$ of the original activity, and then remained stable. It seems at least possible that, given the protracted procedures normally involved in purification, this enzyme may also have two activities, one of which is unstable and is lost during the purification process. It is not yet clear whether the methyltransferase activity detected in $A$. nidulans extracts is due to one single enzyme, or whether it is a mixture of different proteins perhaps active against different products. Work to clarify this question is currently in progress. Other groups working with Saccharomyces cerevisiae have reported that no methyltransferase activity can be detected in this organism (Maga and McEntee, 1985), so that $A$. nidulans appears particularly well suited amongst the lower eukaryotes as a candidate for the study of alkylation damage repair.

Amongst the mutants isolated as showing hypersensitivity to $\mathrm{MNNG}$, however, we have been unable to detect a defect in either of the two enzymes we have characterized, demonstrating that repair of alkyl lesions is likely to be complex and may involve several gene products. The demonstration that the sagC3 mutant and the sagC3; sagAl double mutant are both UV-sensitive when 
irradiated at the germling stage also indicates that the defects in these strains are unlikely to be in enzymes or other proteins primarily involved in the repair of alkylation damage.

Of the five MNNG-sensitive mutants isolated in this work, each appeared to be due to a single mutation which is recessive to the wild-type gene. The sagC3 and sagE5 alleles were mapped to chromosome I and VI respectively, while sagAI and $\operatorname{sagB} 2$ both mapped to chromosome VIII and were separated by 30 map units. Sag4 also mapped to chromosome VIII but has yet to be shown to be in a different gene to $\operatorname{sag} A 1$ or $\operatorname{sagB2}$.

With respect to the epistatic relationships, sagA1 and sagB2 although mapping on the same chromosome clearly do not belong in the same group (i.e. they are presumably both involved in different repair pathways), as is shown by the increased sensitivity of the $\operatorname{sag} A 1, \operatorname{sag} B 2$ double mutant. In the same way, $\operatorname{sag} A 1$ and $\operatorname{sag} C 3$ are also in different epistatic groups. Unlike other groups (e.g. Käfer and Mayor, 1986) we have experienced no difficulties in constructing non-epistatic double mutants. Both the $\operatorname{sag} A 1, \operatorname{sag} B 2$ and the sagC3; sagAI double mutants have normal morphology and behave very much like a wild-type strain except when exposed to alkylating agents.

When sagC3 was mapped to chromosome I we were concerned that this mutation might be allelic to the $u v s F$ and/or $u v s A$ gene which both affect DNA repair and have also been mapped to this chromosome (Jansen, 1969; Shanfield and Käfer, 1969). However, the linkage of sagC 3 with adGl and anAl places the sagC 3 gene in a map position quite different from either of these genes. We conclude, therefore, that this mutation lies in a distinct new gene. It has been observed by other workers that mutations in $u v s B$ appear to be particularly common amongst repair mutants of $A$. nidulans selected in a variety of ways (Käfer and Mayor, 1986), but none of the mutants described here mapped to chromosome IV, the location of $u v s B$. We are as yet unable to totally exclude the possibility that either $\operatorname{sag} A I$ or $\operatorname{sag} B 2$ might be allelic to uvsC14 which also maps on chromosome VIII. Both sagAI and sagB2 mutants are completely resistant to UV-irradiation, whether irradiated as conidia or after some hours of germination. Therefore, it seems unlikely that either of these mutations is allelic to uvsC14. In

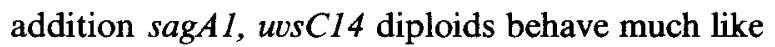
a wild-type strain when exposed to UV at the germling stage. Attempts to map sagAl with respect to flanking markers have proved unsuccessful. This mutation may have an affect on meiotic recombination and thus prevent the fine mapping of this gene. We have also been unable to construct $\operatorname{sag} A 1 / / \operatorname{sag} A 1$ homozygous diploids despite extensive efforts, and we believe it is likely that such a construct would not be viable. Similar behaviour has been reported for another DNA-repair defective (UV sensitive) mutant (Lanier et al., 1968) but its significance is not yet understood. In heterozygous diploids, sagAl appeared to have the effect of increasing damage-induced mitotic allele segregation, as judged by the appearance of sectors in diploids carrying suitable conidia colour markers. These sectors appeared most likely to be due to mitotic recombination since they were of normal appearance and growth pattern and showed none of the growth abnormalities normally associated with aneuploids (Käfer and Upshall, 1973). Further experiments using suitably marked strains to further characterize these mitotic events are currently in progress using the system of Wood and Käfer (1967).

In contrast to the behaviour of $\operatorname{sag} A 1$, the sagC 3 mutation had no effect on the generation of homozygous diploids, and these strains showed the MNNG and UV sensitivities characteristic of the haploid parents. The diploids did, however, show an increase in the spontaneous generation of sectors, and a significant decrease in MNNG induced sectoring. Again, further experiments to characterize these mitotic effects are in progress.

Although it has not been possible to determine the precise nature of the defects in $\operatorname{sagAI}$ and sagC3 mutants, it is apparent that the $\operatorname{sagC} 3$ gene product is involved not only in the repair of alkylation damage, but also in the repair of $U V$ damage, at least at the germling stage. SagAI in contrast does not appear to be involved in the repair of UV damage under normal circumstances, as mutants in this gene display normal UV sensitivity. However the $\operatorname{sagAl}$ gene product may become involved in repair of UV damage in the absence of the sagC3 gene product, as indicated by the increased UV sensitivity of the sagC3; 
sagAl double mutant compared to the sagC3 single mutant. Thus the defects in $s a g A l$ and sagC3 affect the repair of lesions induced by UV, MNNG, MMS and EMS, implying a role for their gene products in the repair of each of these types of lesion. It is possible that at least one of our mutants is defective in some cellular regulatory role not specific for DNA repair. Recently it has been shown that the rad6 mutants of Saccharomyces cerevisiae are defective in a ubiquitinconjugating enzyme (Jentsch et al., 1987). This defect confers sensitivity to UV, X-rays, chemical mutagens and total deficiency in mutagenesis. It has been suggested that the RAD6 protein-mediated ubiquitination of chromosomal proteins (e.g. histones $\mathrm{H} 2 \mathrm{~A}$ and $\mathrm{H} 2 \mathrm{~B}$ ) may be partly responsible for specific alterations in chromatin that may be required for DNA repair.

The isolation and characterization of the mutants described in this paper increases the number of genes known to be involved in DNA repair in Aspergillus nidulans. While our understanding of the genetics of DNA repair processes in this lower eukaryote are not yet as well developed as they are in yeast, it is clear that Aspergillus has several unique features which make it advantageous as an organism in which to study DNA repair. The availability of an efficient transformation system for this organism (Ballance and Turner, 1985) makes the screening of gene banks a feasible proposition and using this technique we have recently cloned DNA sequences which complement the sagAl and sagC3 deficiencies. Further details of this work will be published elsewhere.

\section{References}

Abbott, P.J., and R. Saffhill (1979) DNA synthesis with methylated poly(dC-dG) templates, Evidence for a competitive nature to miscoding by $O^{6}$-methylguanine, Biochim. Biophys. Acta, 562, 51-61.

Ballance, D.J., and G. Turner (1985) Development of a highfrequency transforming vector for Aspergillus nidulans, Gene, 36, 321-323.

Bogden, J.M., A. Eastman and E. Bresnick (1981) A system in mouse liver for repair of $O^{6}$-methylguanine lesions in methylated DNA, Nucleic Acids Res., 9, 3089-3103.

Cairns, J., P. Robins, B. Sedgwick and P. Talmud (1981) The inducible repair of alkylated DNA, Progr. Nucleic Acid Res. Mol. Biol., 26, 237-244.
Cove, D.J. (1966) The induction and repression of nitrate reductase in the fungus Aspergillus nidulans, Biochim. Biophys. Acta, 113, 51-56.

Dolan, M.E., D. Scicchitano, B. Singer and A.E. Pegg (1984) Comparison of repair of methylated pyrimidines in poly(dT) by extracts from rat liver and Escherichia coli, Biochem. Biophys. Res. Commun., 123, 324-330.

Evensen, G., and E. Seeberg (1982) Adaptation to alkylation resistance involves induction of a DNA glycosylase, Nature (London), 296, 773-775.

Hastie, A.C. (1970) Benlate-induced instability of Aspergillus diploids, Nature (London), 226, 771.

Jansen, G.J.O. (1969) Location and designation of some uvs loci in Aspergillus nidulans, Aspergillus Newslett., 10, 23-24.

Jansen, G.J.O. (1970) Survival of uvsB and uvs $C$ mutants of Aspergillus nidulans after UV-irradiation, Mutation Res., 10, 21-32.

Jentsch, S., J.P. McGrath and A. Varshavsky (1987) The yeast DNA repair gene RAD6 encodes a ubiquitin-conjugating enzyme, Nature (London), 329, 131-134.

Käfer, E. (1958) A 8-chromosome map of Aspergillus nidulans, Adv. Genet., 9, 105-145.

Käfer, E. (1987) MMS sensitivity of all amino acid-requiring mutants in Aspergillus and its suppression by mutations in a single gene, Genetics, 115, 671-676.

Käfer, E., and O. Mayor (1986) Genetic analysis of DNA repair in Aspergillus: evidence for different types of MMSsensitive hyperrec mutants, Mutation Res., 161, 119-134.

Käfer, E., and A. Upshall (1973) The phenotypes of eight disomics and trisomics of Aspergillus nidulans, Heredity, 64, 35-38

Lanier, W.B., R.W. Tuveson and J.E. Lennox (1968) A radiation-sensitive mutant of Aspergillus nidulans, Mutation Res., 5, 23-31.

Laval, F., and J. Laval (1984) Adaptive response in mammalian cells: cross-reactivity of different pretreatments on cytotoxicity as contrasted to mutagenesis, Proc. Natl. Acad. Sci. (U.S.A.), 81, 1062-1066.

Lawley, P.D. (1966) Effects of some chemical mutagens and carcinogens on nucleic acids, Progr. Nucleic Acid Res., 5, 89-131.

Lawley, P.D., and C.J. Thatcher (1970) Methylation of deoxyribonucleic acid in cultured mammalian cells by $N$ methyl- $N^{\prime}$-nitro- $N$-nitrosoguanidine, Biochem. J., 116, 693-707.

Lindahl, T. (1982) DNA repair enzymes, Annu. Rev. Biochem., $5161-87$.

Maga, J.A., and K. McEntee (1985) Response of $S$. cerevisiae to $N$-methyl- $N^{\prime}$-nitro- $N$-nitrosoguanidine: mutagenesis, survival and DDR gene expression, Mol. Gen. Genet., 200, 313-321.

Margison, G.P., D.P. Cooper and J. Brennand (1985) Cloning of the $E$. coli $O^{6}$-methylguanine and methyl phosphotriester methyl transferase gene using a functional DNA repair assay, Nucleic Acids Res., 13, 1939-1952.

McCarthy, T.V., P. Karran and T. Lindahl (1984) Inducible repair of $\boldsymbol{O}$-alkylated DNA pyrimidines in Escherichia coli, EMBO J., 3, 545-550. 
Mehta, J.R., D.B. Ludlum, A. Renard and W.G. Verly (1981) Repair of $O^{6}$-ethylguanine in DNA by a chromatin fraction from rat liver: Transfer of the ethyl group to an acceptor protein, Proc. Natl. Acad. Sci. (U.S.A.), 78, 6766-6770.

Olsson, M., and T. Lindahl (1980) Repair of alkylated DNA in Escherichia coli methyl group transfer from $O^{6}$-methylguanine to a protein cysteine residue, J. Biol. Chem., 225, 10569-10571.

Pegg, A.E., M. Roberfroid, C. von Bahr, R.S. Foote, S. Mitra, H. Bresil, A. Likhachev and R. Montesano (1982) Removal of $O^{6}$-methylguanine from DNA by human liver fractions, Proc. Natl. Acad. Sci. (U.S.A.), 79, 5162-5165.

Pegg, A.E., L. Weist, R.S. Foote, S. Mitra and W. Perry (1983) Purification and properties of $O^{6}$-methylguanine-DNA transmethylase from rat liver, J. Biol. Chem., 258, 2327-2333.

Pontecorvo, G., J.A. Roper, L.M.C. Hemmons, F.D. McDonald and A.W.J. Bufton (1953) The genetics of Aspergillus nidulans, Adv. Genet., 5, 141-238.

Samson, L., and J. Cairns (1977). A new pathway for DNA repair in Escherichia coli, Nature (London), 267, 281-283.

Samson, L., and J.L. Schwarz (1980) Evidence for an adaptive DNA repair pathway in $\mathrm{CHO}$ and human skin fibroblast cell lines, Nature (London), 287, 861-863.
Seeberg, E., J. Nissen-Meyer and P. Strike (1976) Incision of ultraviolet-irradiated DNA by extracts of $E$. coli requires three different gene products Nature (London), 263, 524-525.

Sekiguchi, M., and Y. Nakabeppu (1987) Adaptive response: induced synthesis of DNA repair enzymes by alkylating agents, Trends Genet., 3, 51-54.

Shanfield, B., and E. Käfer (1969) UV-sensitive mutants increasing mitotic crossing-over in Aspergillus nidulans, Mutation Res., 7, 485-487.

Teo, I., B. Sedgwick, B. Demple, B. Li and T. Lindahl (1984) Induction of resistance to alkylating agents in $E$. coli: the $\mathrm{ada}^{+}$gene product serves both as a regulatory protein and as an enzyme for repair of mutagenic damage EMBO J., 3, 2151-2157.

Wood, S., and E. Käfer (1967) Twin spots as evidence for mitotic crossing-over in Aspergillus induced by ultra-violet light, Nature, (London), 216, 63-64.

Yarosh, D.B., R.S. Foote, S. Mitra and R. Day III (1983) Repair of $O^{6}$-methylguanine in DNA by demethylation is lacking in $\mathrm{Mer}^{-}$human tumour cell lines, Carcinogenesis, 4, 199-205. 